Науковий вісник НлТУ України Scientific Bulletin of UNFU

https://nv.nltu.edu.ua

https://doi.org/10.15421/40290603

Article received 03.06.2019 p.

Article accepted 27.06.2019 p.

удк 630*43:502.2

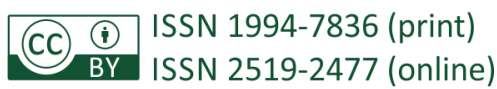

$@ \bowtie$ Correspondence author

O. M. Soshenskyi

soshenskyi@nubip.edu.ua

С. В. Зібцев, В. В. Миронюк, О. М. Сошенський, М. С. Корень, В. А. Корень

Національний університет біоресурсів і природокористування України, м. Київ, Україна

\title{
ПРОСТОРОВО-ЧАСОВИЙ РОЗПОДІЛ ПОЖЕЖ У ПРИРОДНИХ ЛАНДШАФТАХ РІВНЕНСЬКОЇ ОБЛАСТІ
}

\begin{abstract}
Аналіз історичної динаміки пожеж та встановлення їх просторово-часових особливостей є основою для розроблення плану управління пожежами та стратегічного розміщення протипожежних сил і засобів на місцевості, а також здійснення попереджувальних заходів. Використовуючи дані дистанційного зондування Землі, отримано основні показники горючості природних територій Рівненської області за період з 2001 по 2018 рр. та виконано їх аналіз. Щорічно на території області відбувається в середньому 190 випадків пожеж на загальній площі 12,6 тис. га. Усереднені дані свідчать про тенденцію до зростання показників горючості території, зокрема середньорічна площа пожеж за період з 2001 по 2018 рр. зросла від 7,4 до 17,8 тис. га. За результатами дослідження встановлено, що найбільше пожеж стається у березні-квітні $(29,6 \%)$, серпні $(32,2 \%)$ та вересні $(19,9 \%)$, що повинно бути основою для максимальної готовності протипожежних служб у ці періоди. Виконано аналіз погодно-кліматичних показників за багаторічний період та досліджено їх зв'язок з основними показникам горючості. Зроблено висновки щодо проблеми пожеж у природних ландшафтах Рівненської області. Наведено недоліки наявної системи моніторингу пожеж як важливої складової системи охорони природних територій від пожеж.

Ключові слова: пожежні режими; пожежі у природних ландшафтах; Рівненська область; горючість; погодно-кліматичні показники; дистанційне зондування Землі.
\end{abstract}

Вступ. Проблема пожеж у природних ландшафтах України на тлі змін клімату, видового складу лісів та землекористування останніми роками актуалізується, що підтверджує багаторічна динаміка пожеж (Zibtsev et al., 2019). Про це свідчать великі лісові пожежі в Чорнобильській зоні відчуження 2015 р., що охопили загальну площу 14,8 тис. га (Evangeliou et al., 2016), пожежа на території Поліського природного заповідника у 2017 році (близько 600 га), пожежа на території ДП "Олешківське лісомисливське господарство" 2018 р. (за даними Державної служби України з надзвичайних ситуацій на площі 580 га, https://ks.dsns.gov.ua/ua/Nadzvichayni-podiyi/10282.html), а також катастрофічні пожежі, які трапились упродовж 2016-2018 pр. в Австралії, Греції, Іспанії, Каліфорнії, Німеччині, Португалії та Швеції. За даними Державної служби України з надзвичайних ситуацій (ДСНС України), щороку на території нашої країни трапляється близько 30 тис. випадків природних пожеж на загальній площі близько 20 тис. га (Melchutskyi, 2019).

Ключовим чинником, який визначає пожежну небезпеку природних ландшафтів, є погодно-кліматичні умови, джерела вогню та рослинні горючі матеріали. За ре- зультатами останніх досліджень, упродовж останніх десятиліть глобальна температура зросла на $0,8^{\circ} \mathrm{C}$ i сьогодні кліматична система світу знаходиться на шляху підвищення середньої температури до $+4{ }^{\circ} \mathrm{C}$. Паризька кліматична угода 2015 р. визначила безпечний максимум підвищення температури до $+2{ }^{\circ} \mathrm{C}$ (Shvydenko et al., 2016). Згідно з прогнозами, на території України варто очікувати негативні зміни погодних умов і зростання рівня пожежної небезпеки: підвищення температури повітря, зміщення сезонів, подовження тривалості пожежонебезпечного періоду, збільшення повторюваності та інтенсивності хвиль тепла і стихійних гідрометеорологічних явищ, зміну водних ресурсів місцевого стоку (Balabukh et al., 2016; Shevchenko et al., 2014).

Аналіз багаторічної динаміки пожеж та встановлення їх просторово-часових особливостей повинен бути основою для розробки плану управління пожежами, стратегічного розміщення протипожежних сил і засобів на місцевості, а також здійснення попереджувальних заходів. Сьогодні збір статистичної інформації щодо пожеж у природних екосистемах України на національному рівні здійснюють Державна служба статистики України (Держстат України) та Державна служба Укра-

\section{Інформація про авторів:}

Зібцев Сергій Вікторович, д-р с.-г. наук, професор, кафедра лісівництва. Email: sergiy.zibtsev@nubip.edu.ua

Миронюк Віктор Валентинович, канд. с.-г. наук, доцент, кафедра таксації лісу та лісового менеджменту. Email: victor.myroniuk@nubip.edu.ua; https://orcid.org/0000-0002-5961-300X

Сошенський Олександр Михайлович, канд. с.-г. наук, доцент, кафедра лісівництва. Email: soshenskyi@nubip.edu.ua; https://orcid.org/0000-0002-3028-0723

Корень Марія Сергіївна, здобувач, кафедра таксації лісу та лісового менеджменту. Email: mashkakoren@gmail.com

Корень Володимир Анатолійович, здобувач, кафедра лісівництва. Email: volodymyrkoren@gmail.com

Цитування за ДСТУ: Зібцев С. В., Миронюк В. В., Сошенський О. М., Корень М. С., Корень В. А. Просторово-часовий розподіл пожеж у природних ландшафтах Рівненської області. Науковий вісник НлтУ України. 2019, т. 29, № 6. С. 18-23.

Citation APA: Zibtsev, S. V., Myroniuk, V. V., Soshenskyi, O. M., Koren, M. S., \& Koren, V. A. (2019). Wildfire regimes of natural landscapes of the Rivne region of Ukraine. Scientific Bulletin of UNFU, 29(6), 18-23. https://doi.org/10.15421/40290603 
їни 3 надзвичайних ситуацій. Порівняння офіційних статистичних даних різних відомств про пожежі свідчать про недосконалість системи їх збирання, оскільки офіційна статистика не відображає реальну інформацію та занижує кількісні показники горючості на всій території країни (Evangeliou et al., 2016). Так, для прикладу, Держстат України збирає статистичні дані щодо лісових пожеж, а у ДСНС України відсутня інформація про випадки пожеж, у ліквідації яких вона не брала участі. На основі існуючих в Україні статистичних даних складно виконати аналіз просторового розміщення пожеж - важливого елементу оцінювання горючості території, на якій повинна базуватися система охорони природних ландшафтів від пожеж. Наявність достовірної інформації про лісові пожежі дає змогу виконати адекватний аналіз пожежної ситуації на територіальному рівні, виявити недоліки й удосконалити наявну систему охорони природних ландшафтів від пожеж. Виявлення потенційних ризиків загорання стає підставою для стратегічного розміщення протипожежних сил та засобів, здійснення попереджувальних заходів (Oliveira et al., 2016), а сезонна динаміка пожеж - основою для забезпечення максимальної готовності у відповідні періоди.

На сучасному етапі технології дистанційного зондування Землі часто застосовують для моніторингу змін землекористування та земного покриву, зокрема зумовлених природними пожежами. Можливість одержання щоденної інформації про стан земної поверхні за допомогою супутників Terra та Aqua сприяли широкому використанню даних спектрорадіометра середнього просторового розрізнення MODIS у задачах глобального моніторингу пожеж. Зазначена система забезпечує високу періодичність зйомки однієї й тієї ж місцевості, що дало змогу розробити низку алгоритмів для виявлення пожеж та оцінки їх наслідків (Giglio et al., 2018). За даними серії продуктів MODIS існує можливість здійснювати історичну реконструкцію пожеж, що допомагає розширити уявлення про причини їхнього виникнення, сезонність та інші характеристики. Сучасні ГІС-технології створюють передумови для якісного аналізу причин та умов виникнення пожеж, моделювання ймовірності виникнення та розвитку пожеж на конкретній території (Miller \& Ager, 2013).

Територія Рівненської обл. характеризується високим рівнем ризику виникнення та розвитку пожеж у природних ландшафтах, що підтверджується офіційними даними Держстату України про лісові пожежі, які наведено в статистичних збірниках "Статистичний щорічник України", "Україна у цифрах" та "Україна" (Kompleksni Statystychni Publikatsii, 2000-2017). Для прикладу, в 1992 р. відбулося 574 пожежі на загальній площі 379 га, у 1994 р. - 604 пожежі на площі 401 га, у 1995 р. - 375 пожеж на площі 588 га, у 2002 р. - 430 пожеж на площі 257 га, у 2006 р. - 148 пожеж на площі 243 га, у 2009 р. - 162 пожежі на площі 272 га, у 2014 р. - 178 пожеж на площі 52 га, а середньорічна кількість пожеж за період з 1990 по 2017 рр., становить 150 випадків. Високий ризик виникнення лісових пожеж на території області зумовлений порівняно високою лісистістю території (36,4 \%) та переважанням соснових насаджень у структурі лісового фонду області (66 \%) (Reference book, 2012). Дослідження горючості природних ландшафтів Рівненської обл. за багаторічний період із застосуванням даних Д33 дасть змогу уточнити дані офіційної статистики, оцінити діючу систему моніторингу пожеж, ефективність попереджувальних заходів та потенційні ризики пожеж для регіону загалом. Подібний аналіз важливий для вдосконалення системи охорони лісів від пожеж, а також для формування регіональної та національної політики з проблеми пожеж у природних ландшафтах України.

Мета дослідження полягає в дослідженні багаторічної динаміки кількості та площі пожеж у природних ландшафтах Рівненської обл. за 2001-2018 рр. та їх просторового розміщення, використовуючи дані дистанційного зондування Землі.

Матеріал і методи дослідження. В умовах відсутності достовірних географічно орієнтованих даних про пожежі від землекористувачів єдиним доступним джерелом інформації залишаються дані дистанційного зондування Землі (ДЗ3). 3 метою визначення кількості загорань і площі пожеж за 2001-2018 pp. використано глобальні продукти Д3З системи MODIS, які доступні в растровому форматі в репозиторіях "хмарної" платформи Google Earth Engine (GEE) API (Gorelick et al., 2017). Кількість пожеж, які сталися впродовж 2001-2018 pp. одержано на основі продукту системи MODIS про термальні аномалії - MOD14/MYD14. Відповідно до нього, кожне спрацювання алгоритму $є$ так званою "гарячою точкою" (hotspot), яка відображає координати центра пікселя $1 \times 1$ км, де зафіксовано загорання. Розробники гарантують виявлення активної пожежі площею $100 \mathrm{~m}^{2}$, або тліючої - 1000-2000 м² (Justice et al., 2002). Як наслідок, кожній "гарячій точці" приписується один із трьох рівнів достовірності виявлення: низький (менше від $30 \%$ ), середній (30-80\%), високий (понад $80 \%$ ). У дослідженні аналізували сигнали останніх двох рівнів. Оскільки площа пожежі може виявитися більшою від одного пікселя, ми розглядали групу суміжних пікселів, де протягом однієї доби зафіксували загорання, як один випадок пожежі. Пов'язані з таким алгоритмом помилки ідентифікації пожеж, які тривали більше однієї доби в дослідженні не аналізували.

Для картографування площі згарищ використали інший глобальний продукт системи MODIS - MCD64A1, на якому закартографовано просторове охоплення вигорівших територій із зазначенням орієнтовної дати пожеж (просторове розрізнення 500 м). Відносно свого раннього аналога (MCD45A1), алгоритм картографування згарищ MCD64A1 істотно вдосконалився, зокрема відтепер включає площу малих (до 100 га) згарищ (Giglio et al., 2018). Оскільки дані постачаються у вигляді зведених місячних растрових зображень, інформацію про площу пожеж на території Рівненської обл. одержано для кожного календарного місяця впродовж 2001-2018 pp.

Під час аналізу горючості території враховували всі види природних пожеж - лісові, торф'яні, сільськогосподарські пали тощо. Для дослідження зв'язку між погодними умовами та кількісними показниками горючості території зібрали інформацію про погодно-кліматичні умови регіону дослідження за період 20052018 pр. (для досліджуваної території доступні дані, починаючи 32005 р.). Інформацію отримали за допомогою відкритого ресурсу rp5.ua (http://rp5.ua), який дає змогу отримати архівні дані про погодні умови, зафіксовані на місцевих метеостанціях. Під час аналізу вико- 
ристали дані трьох метеостанцій Рівненської обл.: м. Дубно, м. Рівне та м. Сарни.

Результати дослідження. За наявності горючих матеріалів пожежа може виникнути тільки за певних погодних умов та появи джерела загоряння. Основними причинами виникнення пожеж у природних екосистемах $є$ порушення правил пожежної безпеки під час перебування в лісових масивах, випалювання сухої рослинності, недотримання заходів пожежної безпеки під час виконання польових робіт - тобто людський чинник, що підтверджується даними ДСНС України (Melchutskyi, 2019).

Для аналізу погодних умов за багаторічний період використано щоденні погодні показники, які впливають на пожежну небезпеку ландшафтів: температура повітря, температура точки роси та кількість опадів. На основі цих даних обчислили комплексний показник пожежної небезпеки погоди за методикою В. Г. Нестерова (Ivanov, 2011) та за шкалою класів пожежної небезпеки погодних умов (Polozhennia, 2005); встановили клас пожежної небезпеки погоди (КПНП). Розподіл кількості днів у році за класами пожежної небезпеки погоди навели у таблиці.

Таблиця. Розподіл кількості днів у році за КПНП

\begin{tabular}{|c|c|c|c|c|c|c|}
\hline \multirow{2}{*}{ Рік } & \multicolumn{2}{|c|}{ Клас пожежної небезпеки погоди } & Загальна \\
\cline { 2 - 7 } & 1 & 2 & 3 & 4 & 5 & $\begin{array}{c}\text { кількість } \\
\text { днів }\end{array}$ \\
\hline $2005^{*}$ & 173 & 54 & 60 & 31 & 12 & 330 \\
\hline 2006 & 224 & 59 & 59 & 18 & 5 & 365 \\
\hline 2007 & 190 & 62 & 76 & 32 & 5 & 365 \\
\hline 2008 & 234 & 73 & 49 & 8 & 0 & 364 \\
\hline 2009 & 202 & 52 & 53 & 20 & 38 & 365 \\
\hline 2010 & 208 & 82 & 66 & 8 & 1 & 365 \\
\hline 2011 & 171 & 56 & 73 & 28 & 37 & 365 \\
\hline 2012 & 223 & 53 & 57 & 20 & 11 & 364 \\
\hline 2013 & 204 & 62 & 61 & 20 & 18 & 365 \\
\hline 2014 & 172 & 42 & 102 & 32 & 17 & 365 \\
\hline 2015 & 174 & 55 & 83 & 18 & 35 & 365 \\
\hline 2016 & 183 & 43 & 68 & 28 & 42 & 364 \\
\hline 2017 & 206 & 58 & 80 & 19 & 2 & 365 \\
\hline 2018 & 189 & 27 & 50 & 40 & 59 & 365 \\
\hline 3а період, \% & $\mathbf{5 4 , 3}$ & $\mathbf{1 5 , 3}$ & $\mathbf{1 8 , 5}$ & $\mathbf{6 , 3}$ & $\mathbf{5 , 6}$ & $\mathbf{1 0 0 , 0}$ \\
\hline
\end{tabular}

Примітка: *В архіві даних сайту rp5.ua (http://rp5.ua) інформація за 2005 р. наводиться, починаючи 3 середини лютого, що не впливає на результати досліджень.

Зміни клімату впливають на пожежну небезпеку природних територій, зокрема в межах Рівненської обл. Аналіз динаміки кількості днів, протягом яких зберігається високий ризик виникнення пожеж (4 та 5 КПНП), засвідчив тенденцію до збільшення: середньозважена кількість днів зросла від 24 днів у 2005 р., до 62 днів у 2018 р. (рис. 1).

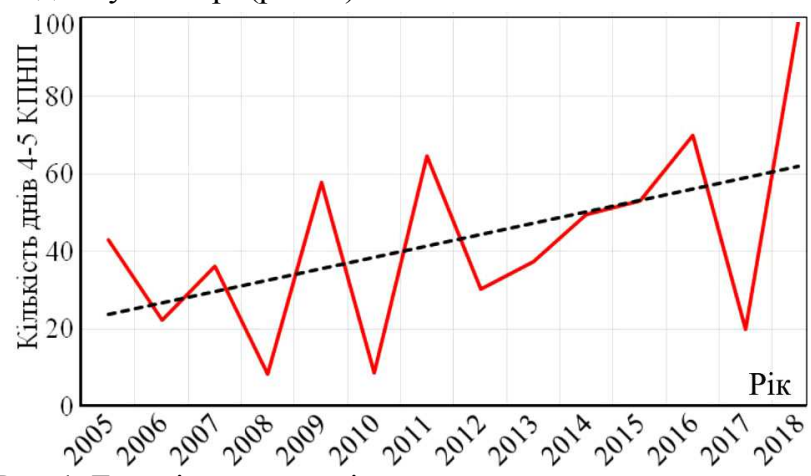

Рис. 1. Динаміка тривалості високої та надзвичайної пожежної

небезпеки за умовами погоди (4-5 КПНП За шкалою класу пожежної небезпеки за умовами погоди) (Polozhennia, 2005) на території Рівненської обл. за період 2005-2018 pp.
Основними показниками пожежної небезпеки території є дані про кількість випадків пожеж, сезонну динаміку, загальну та середню площу пожеж, стан горючих матеріалів і погодно-кліматичні умови. На цій основі повинна формуватися система охорони природних територій від пожеж. Досліджувана територія є одним із центрів горючості в Західному Поліссі. Зокрема в Рівненський обл. кожні 3-7 років спостерігають пожежні максимуми - 2002, 2009, 2012, 2015 та 2018 рр. (рис. 2).

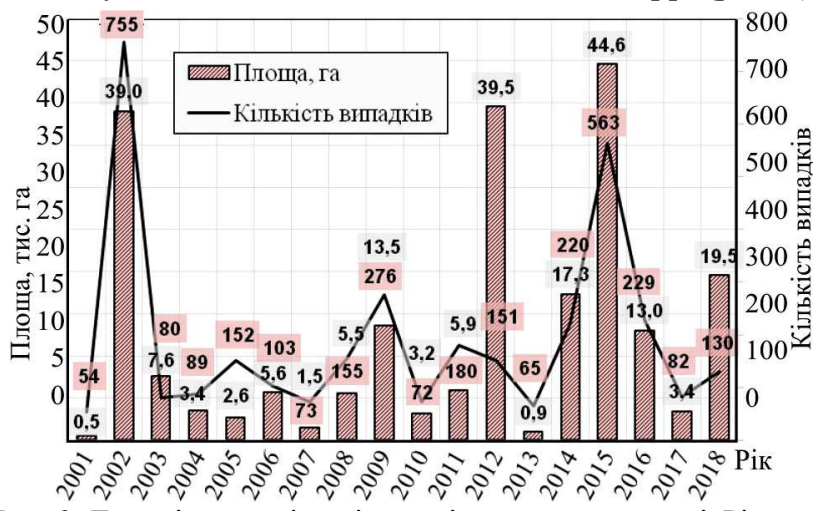

Рис. 2. Динаміка площі та кількості пожеж на території Рівненської обл. упродовж 2001-2018 рр.: кількість пожеж встановлено за даними MOD14/MYD14; площу згарищ оцінено за даними MCD64A1

Дані рис. 2 відображають незалежний від суб'єктивних чинників розподіл кількості та площі всіх пожеж, які трапилися у природних ландшафтах. Згідно з отриманими даними, щорічно у природних ландшафтах Рівненської обл. трапляється у середньому 190 випадків пожеж на загальній площі 12,6 тис. га. Усереднені дані свідчать про тенденцію до зростання показників горючості території, зокрема середньорічна площа пожеж за період з 2001 по 2018 рр. зросла від 7,4 до 17,8 тис. га. При цьому в офіційній інформації Державної служби статистики України наявні тільки дані про лісові пожежі: у 2002 р. виникло 430 пожеж на загальній площі 257 га, у 2009 р. - 162 пожежі на площі 272 га, у 2012 р. - 70 пожеж на площі 64 га, у 2015 р. - 80 пожеж на площі 143 га.

Оскільки систему організації протипожежних служб в Україні побудовано за принципами адміністративнотериторіального устрою, доцільно виконати аналіз пожеж, які відбулися на досліджуваній території в межах адміністративних районів. Дані рис. 3 свідчать про певні територіальні відмінності в розподілі пожеж. Найбільше пожеж, за кількістю та площею, відбулося на території Рокитнівського, Дубровицького, Зарічненського, Володимирецького, Сарненського, Костопільського та Млинівського районів; найменше - на території Радивилівського, Березнівського, Корецького, Острозького та Здолбунівського районів. При цьому простежуємо зв'язок між показниками горючості території та лісистістю адміністративних районів. Винятком $\epsilon$ Березнівський район, де за високої лісистості теритоpiï (50,3\%) показники горючості $\epsilon$ найнижчими 104 випадки пожеж на загальній площі 2,567 тис. га впродовж 2001-2018 рр. Цю ситуацію пояснюємо особливостями лісорослинних умов території, де згідно 3 типологічною сіткою Алєксєєва-Погребняка, переважають вологі та сирі умови. 

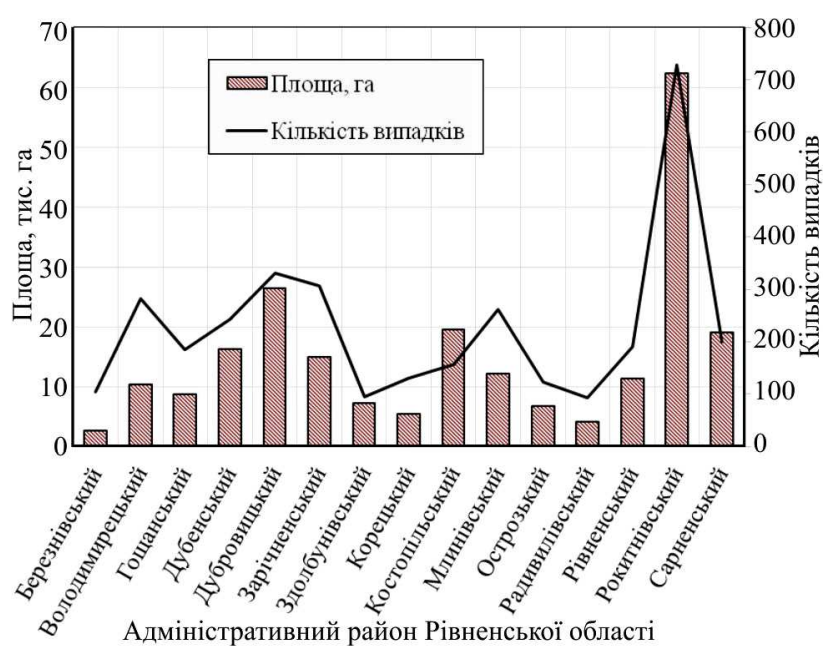

Рис. 3. Кількість та площа пожеж, які відбулися протягом 2001-2018 рр. за адміністративними районами Рівненської обл. за даними MODIS

Окрім узагальнення даних про площу та кількість пожеж у природних ландшафтах, виконали аналіз динаміки пожеж за місяцями календарного року (рис. 4). Інформація про динаміку пожеж упродовж календарного року повинна бути основою для максимальної готовності протипожежних служб до пожежонебезпечного періоду та іiі потрібно використовувати для вживання попереджувальних заходів, планування патрулювання території, розташування протипожежних сил.

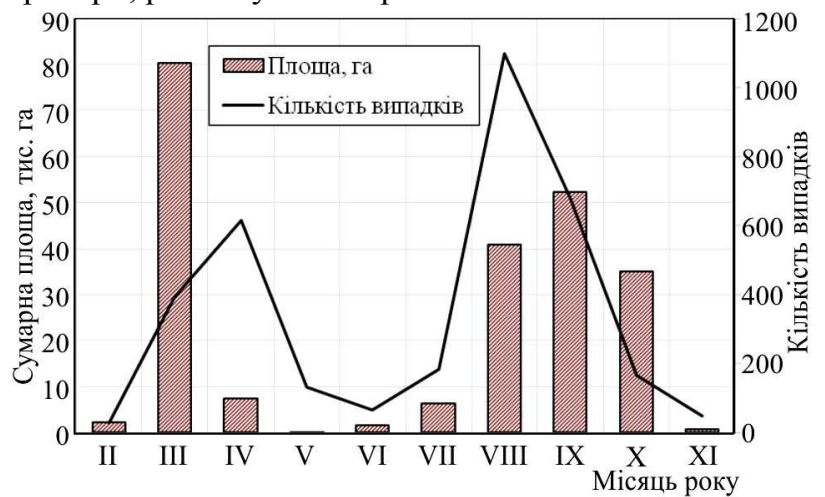

Рис. 4. Сезонна динаміка кількості та площі пожеж у природних ландшафтах Рівненської обл. за 2001-2018 pр. за даними MODIS

Щомісячна динаміка кількості пожеж характеризує рівень пожежної небезпеки та щільності джерел вогню для кожного місяця, тоді як динаміка площі свідчить про ефективність реагування на пожежу. Згідно з даними рис. 4, впродовж року на досліджуваній території спостерігаємо три періоди, протягом яких відбувається найбільше пожеж: весняний - березень-квітень $(29,6 \%)$, літній - серпень (32,2 \%) та осінній - вересень (19,9\%). Весняний пік пов'язаний із накопиченням великої кількості горючих матеріалів за попередній рік (відмерлий живий надгрунтовий покрив), які втрачають вологість 3 підвищенням температури та зниженням відносної вологості повітря з середини березня та початку квітня. Це свідчить про невідповідність загальноприйнятої дати (1 квітня) початку пожежонебезпечного періоду, яка фактично настає раніше. Літньо-осінній пік пояснюємо посушливими умовами протягом липня-серпня (висока температура повітря, низька вологість) та випалюванням рослинних решток на полях після збирання врожаю. Відносно великі площі пожеж, порівняно з кіль- кістю, в березні та жовтні свідчать про недосконалість системи охорони природних територій від пожеж: несвоєчасний початок пожежонебезпечного періоду, недостатньо ефективну систему виявлення пожеж та реагування на них. Зазвичай у ці місяці пожежі стаються на нелісових територіях (випалювання сухої трави навесні та сільськогосподарське паління восени).

Для аналізу зв'язку показників горючості та погодних умов використали дані про кількість пожеж та обчислили комплексний показник пожежної небезпеки погоди, за яким встановили клас пожежної небезпеки погоди (рис. 5).

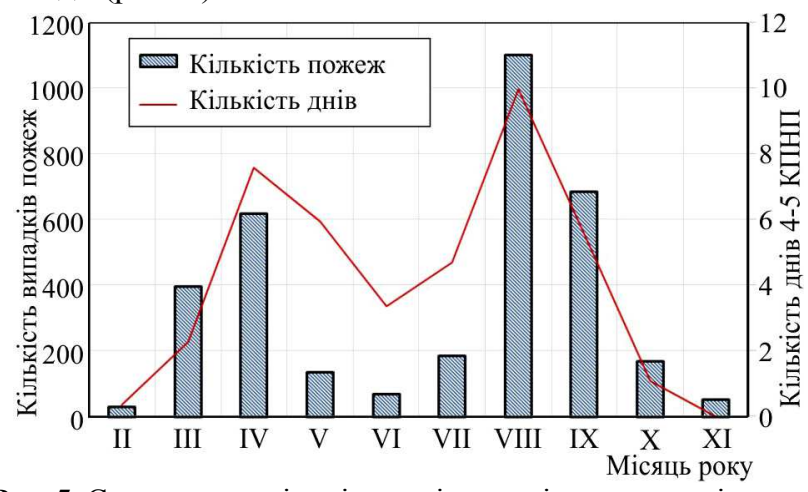

Рис. 5. Сезонна динаміка кількості випадків пожеж та кількості днів із 4 та 5 класом пожежної небезпеки погоди: кількість пожеж одержано за 2001-2018 pp., погодні умови - за 2005-2018 pp.

Дані рис. 5 підтверджують залежність кількості пожеж від тривалості періоду, впродовж якого зберігається висока та надзвичайна небезпека умов погоди (4-5 КПНП). Так, зв'язок між кількістю пожеж та кількістю днів із 4-5 КПНП у березні, квітні, серпні та вересні пояснюємо наявністю сухих горючих матеріалів, натомість відносно невелика кількість пожеж у травні, червні та липні, порівняно 3 кількістю днів 4-5 КПНП, пов'язана 3 тим, що рослини утворюють зелену масу, яка містить велику кількість вологи. Таким чином, пожежі, які стаються у травні-липні - це переважно лісові та торф'яні пожежі. Встановлена середня тривалість періоду з 4-5 КПНП упродовж місяця становить тільки 210 днів. Велика кількість пожеж, що відбувається за цей період, свідчить про нестачу протипожежних сил і засобів для виявлення пожеж та реагування на них або недосконалість наявної системи із запобігання пожежам та швидкого реагування.

Обговорення отриманих результатів. Ефективне управління та вдосконалення системи охорони природних територій від пожеж можливе тільки за наявності повноцінної, достовірної інформації про пожежі на відповідних територіях. Система моніторингу природних пожеж потребує удосконалення та повинна містити в собі інформацію щодо горючості та пірологічної структури лісового фонду, метеорологічних умов, джерел вогню, чинної системи протипожежної охорони тощо. Результати такого моніторингу є основою протипожежного облаштування, ефективної системи оперативного контролю, прогнозування, виявлення та гасіння пожеж. Наявність великих лісових пожеж, які систематично стаються на території України, є свідченням того, що наявна система не враховує всіх чинників, які впливають на горючість території, а політика у сфері охорони природних ландшафтів від пожеж формується на основі неповноцінної інформації. 
Рівненську обл. варто характеризувати високим рівнем ризику виникнення та поширення природних пожеж унаслідок наявності великих площ лісових масивів, сільськогосподарських земель, торфовищ, а також необроблюваних земель. Динаміка пожеж у природних ландшафтах області свідчить про тенденцію до зростання показників горючості території. Так, тренд кількості пожеж за період 2001-2018 рр. майже не змінився - у середньому відбувається близько 200 пожеж щороку, проте площа пожеж за цей період зросла від 7,4 до 17,8 тис. га.

Інформація, отримана в межах цього дослідження, свідчить про актуалізацію проблеми пожеж у природних ландшафтах Рівненської обл. Тому місцевим органам влади та протипожежним службам потрібно приділити більше уваги для вирішення цієї проблеми із застосуванням інтегрованого підходу. Представлену динаміку пожеж можна використати як статистичну основу для контролю якості імітаційного моделювання ризиків, зумовлених природними пожежами, а також під час розроблення систем прийняття рішень.

Висновки. Результати дослідження мають вагоме значення для практики управління природними пожежами та подальшого розвитку методів дослідження горючості ландшафтів. У регіоні щорічно стається в середньому 190 випадків пожеж на загальній площі 12,6 тис. га., найчастіше пожежі трапляються в березніквітні (29,6\%), серпні (32,2\%) та вересні (19,9\%). 3 метою кращого запобігання та гасіння такої значної кількості пожеж необхідно оцінити наявні ресурси 3 врахуванням сезонної динаміки горючості, що створить передумови для підвищення рівня готовності протипожежних служб у ці періоди. Враховуючи показники горючості в межах адміністративних районів Рівненської обл., найбільшу увагу до питання охорони природних ландшафтів від пожеж потрібно приділяти на території Рокитнівського, Дубровицького, Зарічненського, Володимирецького та Млинівського районів. Враховуючи те, що є висока вірогідність збереження встановленого тренду до зростання щорічної кількості днів з високою та надзвичайною пожежною небезпекою погоди, кількість яких за 13 років зросла у 2,5 раза і сягнула 62 дні, потрібно бути готовим до посилення проблеми природних пожеж у майбутньому, що має бути враховано у системі охорони природних ландшафтів від пожеж.

\section{Перелік використаних джерел}

Balabukh, V. O., \& Zibtsev, S. V. (2016). Climate change impact on number and area of forest fires in northern Black sea region. Ukrainian Hydrometeorological Journal, 18, 60-71. [In Ukrainian].

Complex. (2018). Complex Statistical Publications. State Statistics Service of Ukraine. Retrieved from: https://ukrstat.org/uk/druk/publicat/kat u/publ1 u.htm. [In Ukrainian].

Evangeliou, N., Zibtsev, S., Myroniuk, V., Zhurba, M., et al. (2016). Resuspension and atmospheric transport of radionuclides due to wildfires near the Chernobyl Nuclear Power Plant in 2015: An impact assessment., Sci. Rep.-UK, 6, 26062. https://doi.org/10.1038/srep26062

Fire Information. (2019). Fire Information for Resource Management System. Earthdata. (Database). Obtained Jan 27, 2019. Retrieved from: https://earthdata.nasa.gov/earth-observation-data/near-real-time/firms

Giglio, L., Boschetti, L., Roy, D. P., Humber, M. L., \& Justice, C. O. (2018). The Collection 6 MODIS burned area mapping algorithm and product. Remote Sensing of Environment, 217, 72-85. https://doi.org/10.1016/j.rse.2018.08.005

Gorelick, N., Hancher, M., Dixon, M., Ilyushchenko, S., Thau, D., \& Moore, R. (2017). Google Earth Engine: Planetary-scale geospatial analysis for everyone. Remote Sensing of Environment, 202, 18-27. https://doi.org/10.1016/j.rse.2017.06.031

Ivanov, V. A., Ivanova, G. A., \& Moskovchenko, S. A. (2011). Guidelines for wildfire suppression. (2nd ed.). Krasnoyarsk. [In Russian].

Justice, C., Giglio, L., Korontzi, S., Owens, J., et al. (2002). The MODIS fire products. Remote Sensing of Environment, 83(1-2), 244 262. https://doi.org/10.1016/S0034-4257(02)00076-7

Kashparov, V. A., Zhurba, M. A., Kireev, S. I., Zibtsev, S. V., \& Myroniuk, V. V. (2015). Evaluation of the expected doses of fire brigades at the Chornobyl exclusion zone in April 2015. Nuclear Physics and Atomic Energy. 16(4), 399-407. https://doi.org/10.15407/jnpae2015.04.399

Kashparov, V. A., Myroniuk, V. V., Zhurba, M. A., Zibtsev, S. V., Glukhovskiy, A. S., \& Zhukova, O. M. (2017). Radiological Consequences of the Fire in the Chernobyl Exclusion Zone in April 2015. Radiation biology Radioecology, 57(5), 512-527. [In Russian].

Key, C. H., \& Benson, N. C. (2006). Landscape Assessment, 55 p. Retrieved from: https://www.fs.fed.us/postfirevegcondition/documents/publications/FIREMON LandscapeAssessment.pdf

Melchutskyi, O. (2019). Every year the situation with fires in forests, peatlands and areas in open areas remains difficult. The State Emergency Service of Ukraine. Retrieved from: https://rv.dsns.gov.ua/ua/Ostanni-novini/13455.html. [In Ukrainian].

Miller, C., \& Ager, A. A. (2013). A review of recent advances in risk analysis for wildfire management. International Journal of Wildland Fire, 22(1), 1. https://doi.org/10.1071/WF11114

Oliveira, T. M., Barros, A. M. G., Ager, A. A., \& Fernandes, P. M. (2016). Assessing the effect of a fuel break network to reduce burnt area and wildfire risk transmission. International Journal of Wildland Fire, 25(6), 619. https://doi.org/10.1071/WF15146

Provision. (2005). Provision on Forest Fire Stations. Legislation of Ukraine. Retrieved from: https://zakon.rada.gov.ua/laws/show/z0047-06. [In Ukrainian].

Reference book. (2012). Reference book of forest resources of Ukraine: according to state forest records as of 01.01.2011. Irpin: PA "Ukrderzhlisproekt". [In Ukrainian].

Shevchenko, O., Vlasiuk, O., Stavchuk, I., Vakoliuk, M., et al. (2014). Climate Vulnerability Assessment: Ukraine. Climate Forum East (CFE). Working Group on Climate Change Civic Organizations. Myflaer. Kyiv. Retrieved from: http://necu.org.ua/wp-content/uploads/ukraine cc vulnerability.pdf. [In Ukrainian].

Shvydenko, A., Buksha, I., \& Krakovska, S. (2016). Strengthening Ukraine's ability to assess the vulnerability of plain forests to climate change. Clima East project report, CEEF2015-036-UA.

Zibtsev, S., Soshenskyi, O., \& Koren, V. (2019). Long term dynamic of forest fires in Ukraine. Ukrainian journal of forest and wood science. Articles in Press. 3. [In Ukrainian].

S. V. Zibtsev, V. V. Myroniuk, O. M. Soshenskyi, M. S. Koren, V. A. Koren National University of Life and Environmental Sciences of Ukraine, Kyiv, Ukraine

\section{WILDFIRE REGIMES OF NATURAL LANDSCAPES OF THE RIVNE REGION OF UKRAINE}

Integrated fire management during the epoch of climate and land use change need to be organized on landscape level on the basis of strong vertical and horizontal co-operation between forestry and emergency agencies and local communities and requires clear understanding of fire regime and factors that it determined both in temporal and spatial aspects. For this purpose, fire regimes of natural and cultural landscapes of Rivne Oblast, Ukraine, for the period of 2001-2018 were studied based on remote sensing data. For getting better understanding of long-term pathways of wildfire regimes of natural landscapes of Rivne Oblast of Ukraine, we used data about hotspots from MOD14/MYD14 for number of fires, data about contours and areas of fires from MCD64A1 and Landsat 8 OLI 
with classification of all fires on different levels of intensity and landcover type and data from three local meteorological stations on the fire weather danger level. The study showed that in Rivne Oblast for the period 7 fire maximums occurred, in particularly in 2002, 2009, 2012, 2015 and 2018. Official statistical data presents essentially underestimated area of fires: 257 ha in 2002 (while this study shows 750 ha based on RS data or 143 ha in 2015 (563 ha based on RS data). On average during the period, 190 wildfires with a total area of 12.6 thousand hectares occurred annually in landscapes of Rivne Oblast. The highest amount of fires occurred in the north part of the region - Rokytnivskii (62 000 ha burned), Dubrovitskii (26000 ha), Kostopilskii (19 400 ha), Zarichnenskii (14 900 ha), Volodymyretskii (10 300 ha) districts. The main driver of fires is drought periods: $54.3 \%$ of days in fire season determined as highest emergency level fire weather class - V, $15.3 \%$ days - IV class, $18.5 \%$ - III class. High level of fire weather danger in the region and permanent presence of ignition sources of human origin determine seasonal patterns of burning. Seasonal fire peaks occur in March (80 000 ha burned)-April (87 300 ha burned or $29.6 \%$ of the average number of wildfires), August (32.2\%) and September $(19.9 \%)$ - totally 127000 ha burned, when the maximum level of preparedness of fire-fighting brigades should be provided. Long-term dynamic showed increase of the average annual fire area for the period from 7.4 to 17.8 thousand hectares. The increase of annual amount of days with high and emergency fire whether levels from 24 to 62 during last 13 years is detected. Shortcomings of the existing system of statistical data collection on wildfires as an important component of fire management are discussed.

Keywords: fire regimes; landscape fires; Rivne region of Ukraine; fire weather; GIS and remote sensing. 